\title{
Genetics and Disease of Ventricular Muscle
}

\author{
Diane Fatkin ${ }^{1,2,3}$, Christine E. Seidman ${ }^{4,5}$, and Jonathan G. Seidman ${ }^{4}$ \\ ${ }^{1}$ Molecular Cardiology and Biophysics Division, Victor Chang Cardiac Research Institute, Darlinghurst, \\ New South Wales 2010, Australia \\ ${ }^{2}$ Cardiology Department, St Vincent's Hospital, Darlinghurst, New South Wales 2010, Australia \\ ${ }^{3}$ Faculty of Medicine, University of New South Wales, Kensington, New South Wales 2052, Australia \\ ${ }^{4}$ Department of Genetics, Harvard Medical School, Boston, Massachusetts 02115 \\ ${ }^{5}$ Department of Medicine and the Howard Hughes Medical Institute, Brigham and Women's Hospital, \\ Boston, Massachusetts 02115 \\ Correspondence: d.fatkin@victorchang.edu.au
}

Cardiomyopathies are a heterogeneous group of heart muscle diseases associated with heart failure, arrhythmias, and death. Genetic variation has a critical role in the pathogenesis of cardiomyopathies, and numerous single-gene mutations have been associated with distinctive cardiomyopathy phenotypes. Contemporaneously with these discoveries, there has been enormous growth of genome-wide sequencing studies in large populations, data that show extensive genomic variation within every individual. The considerable allelic diversity in cardiomyopathy genes and in genes predicted to impact clinical expression of disease mutations indicates the need for a more nuanced interpretation of single-gene mutation in cardiomyopathies. These findings highlight the need to find new ways to interpret the functional significance of suites of genetic variants, as well as the need for new disease models that take global genetic variant burdens, epigenetic factors, and cardiac environmental factors into account.

$\mathrm{C}^{2}$ ardiomyopathies are broadly defined as diseases of the heart muscle, and the ventricles are involved in most cases. These disorders are relatively common, occurring in one in 500 individuals, and are associated with an increased risk of heart failure, heart transplantation, malignant cardiac arrhythmias, stroke, and sudden death. Because of this high prevalence and substantial morbidity and mortality, cardiomyopathies represent a major health-care burden and cost to the community. Since the discovery of the first genetic cause of an inherited cardiomy- opathy more than two decades ago (GeisterferLowrance et al. 1990), linkage analysis and candidate gene screening in families and sporadic cases have identified hundreds of mutations in genes encoding diverse subcellular components of the cardiomyocyte (Seidman and Seidman 2011; Watkins et al. 2011). Despite these efforts, the genetic basis of disease in many families is unknown, and the promise of gene-based treatments has been largely unmet. Recently, nextgeneration sequencing technologies have ushered in a new era of discovery for understanding

Editors: Margaret Buckingham, Christine L. Mummery, and Kenneth R. Chien

Additional Perspectives on The Biology of Heart Disease available at www.perspectivesinmedicine.org

Copyright (C) 2014 Cold Spring Harbor Laboratory Press; all rights reserved; doi: 10.1101/cshperspect.a021063

Cite this article as Cold Spring Harb Perspect Med 2014;4:a021063 
D. Fatkin et al.

the genetic underpinnings of human disease, and nowhere is this more apparent than in the field of cardiomyopathies. Sequencing a person's entire genome is both feasible and affordable, and initial studies have revealed an extraordinary extent of genetic variation in every person. A significant and surprising finding has been that affected and unaffected individuals carry numerous novel and potentially diseasecausing variants (including nonsense, frameshift insertion/deletions, and splice-site-altering variants) in cardiomyopathy genes. These observations raise important questions about how to interpret the clinical significance of any single variant and the potential need to consider the role of combinations of variants in disease pathogenesis. The genetics revolution will undoubtedly challenge current mechanistic paradigms for inherited cardiomyopathies and may profoundly impact patient management. As genome sequencing has begun to enter "the clinic," it is timely to review what is known about the genetics of cardiomyopathies, insights gained to date from personal genome sequencing, and future directions.

\section{DEFINITIONS}

Classification methods for stratifying subtypes of cardiomyopathies have evolved over time. In 1980, the World Health Organization (WHO) defined cardiomyopathies as "heart muscle diseases of unknown cause" (WHO/ISFC Task Force 1980). This was updated in 1995 to "diseases of myocardium associated with cardiac dysfunction" and included hypertrophic cardiomyopathy (HCM), dilated cardiomyopathy (DCM), arrhythmogenic right ventricular cardiomyopathy (ARVC), and restrictive cardiomyopathy (RCM) (Richardson et al. 1995). The most current consensus definition was formulated in 2006 by an expert panel composed of members of four working groups of the American Heart Association: "Cardiomyopathies are a heterogeneous group of diseases of the myocardium associated with mechanical, and/or electrical dysfunction that usually (but not invariably) show inappropriate ventricular hypertrophy or dilatation and are a result of a variety of causes that frequently are genetic." This definition encompassed genetic and nongenetic causes of HCM, DCM, ARVC, and RCM and, for the first time, included a range of cardiac rhythm abnormalities under the umbrella of "electrical" muscle disorders (Maron et al. 2006). Although each of the cardiomyopathies can be defined by characteristic features, making a diagnosis in an individual case is not always straightforward owing to the frequent occurrence of overlapping phenotypic manifestations. For example, left ventricular systolic dysfunction can develop in patients with endstage HCM, ARVC, LVNC, and RCM; left ventricular diastolic dysfunction can be seen in patients with HCM or DCM; and ventricular arrhythmias can occur with any of the cardiomyopathies. The imprecision of defining cardiomyopathies based on clinical features creates a need for improved classification systems. However, as outlined in subsequent sections of this review, gene-based classifications improve specificity better than labels such as "diseases of the sarcomere" and "diseases of the cytoskeleton" and when combined with conventional morphological descriptors (HCM/DCM) can indicate clinically meaningful mechanisms. For example, recognition that DCM is caused by either an MYH7 or LMNA mutation implies that either diminished motor function (MYH7) or increased sensitivity to biophysical stress (LMNA) is involved, information that could indicate distinct therapeutic strategies. With the emergence of mechanism-based therapies for cardiomyopathies, incorporation of genetic etiology into classification systems will be increasingly meaningful to clinicians.

\section{FROM PHENOTYPE TO GENOTYPE}

Genetics studies of cardiomyopathies have typically started with cardiomyopathy phenotypes and sought to identify associated genotypes. These studies have been undertaken using genome-wide linkage analysis in large kindreds followed by resequencing of promising candidate genes within the linkage interval, or direct candidate gene screening in small families or cohorts of unrelated sporadic cases. Several cri- 
teria have been used to support specific variants as potentially being disease causing, including cosegregation with affection status in families, absence from a control population (typically more than 100 healthy subjects), location at a residue that is highly conserved across species, protein-altering variant type (nonsense, frameshift insertion-deletion, splice site change, nonsynonymous), and predicted or experimentally validated functional effects. Because criteria for candidate gene selection often include cardiac expression, known functions in the heart, and functional similarity to established disease genes, analyses are inherently biased by current concepts of disease pathogenesis and may result in overestimation of the relative importance of some gene groups. Variants in numerous genes have been identified with each of the cardiomyopathies and functionally linked to myocardial defects.

\section{Hypertrophic Cardiomyopathy}

HCM is characterized by the presence of left ventricular hypertrophy that occurs in the absence of associated cardiac or systemic disorders. The diagnosis is made on the basis of left ventricular wall thickness determined by echocardiography or cardiac magnetic resonance imaging. Disproportionate hypertrophy of the interventricular septum is frequently seen, although other patterns may occur, including diffuse thickening with noncontiguous areas of hypertrophy or focal thickening confined to specific regions such as the ventricular apex (Maron and Maron 2013). The severity of hypertrophy can vary from massive to mild, with some genotype-positive individuals having little or no hypertrophy (Klues et al. 1995; Watkins et al. 1995; Maron and Maron 2013). Left ventricular chamber size is normal or small, and systolic function is normal or hyperdynamic. Other echocardiographic features that may be seen include left ventricular outflow tract obstruction and mitral valve abnormalities. Although cardiac biopsy is not required for the diagnosis of HCM and is rarely performed, there are characteristic histopathological features of myocyte hypertrophy, myofiber disarray, and interstitial fibrosis. Complications of HCM include heart failure caused by left ventricular diastolic dysfunction in those with preserved left ventricular systolic function or left ventricular systolic dysfunction in a minority of cases with end-stage disease. Left ventricular diastolic abnormalities may also cause left atrial dilation, and atrial fibrillation is seen in $20 \%$ of patients (Olivotto et al. 2001). Sudden cardiac death caused by ventricular arrhythmias is a devastating but relatively infrequent complication and is mainly seen in younger patients (Maron and Maron 2013). The differential diagnosis of HCM includes physiological causes of left ventricular hypertrophy such as athlete's heart, cardiac metabolic storage disorders, and a range of secondary causes of hypertrophy (Maron et al. 2006).

Individuals with HCM may have a positive family history, with an autosomal-dominant inheritance pattern, or present as a sporadic case. More than 1400 mutations have been associated with HCM, the majority of these located in genes that encode proteins in the thick and thin filaments of the sarcomere, with a small number of mutations also seen in genes encoding Z-disc components and calcium-handling proteins (Table 1). The precise number of disease genes for HCM has been debated, ranging from eight to 11 or more depending on varying interpretation of the evidence for pathogenicity (Hershberger et al. 2009; Seidman and Seidman 2011; Watkins et al. 2011; Landstrom and Ackerman 2012; Maron et al. 2012; Maron and Maron 2013; Teekakirikul et al. 2013). Mutations in MYH7, which encodes the $\beta$-myosin heavy chain, and MYBPC3, which encodes cardiac myosin-binding protein $\mathrm{C}$, each account for $30 \%-40 \%$ of genotyped cases. Genetic testing of known disease genes usually detects mutations in $\sim 60 \%$ of familial cases and $40 \%$ of sporadic cases (Ho 2010). In testing panels, it is useful to include the PRKAG2, LAMP2, and GLA genes that encode the $\gamma$-regulatory subunit of the AMP-activated protein kinase, lysosome-associated membrane protein-2, and $\alpha$-galactosidase, respectively, as these have been associated with phenotypes that can mimic HCM (Sachdev et al. 2002; Arad et al. 2005). 
D. Fatkin et al.

Table 1. Genes associated with childhood-onset and adult-onset cardiomyopathies and related phenotypes

\begin{tabular}{|c|c|c|c|c|c|c|c|c|}
\hline Gene & & $\mathrm{HCM}$ & DCM & LVNC & $\mathrm{RCM}$ & ARVC & $\begin{array}{l}\text { Arrhythmic } \\
\text { syndromes }^{\text {a }}\end{array}$ & Other \\
\hline \multicolumn{9}{|c|}{ Sarcomere } \\
\hline ACTC1 & Cardiac actin & $\mathrm{X}$ & $\mathrm{X}$ & $\mathrm{X}$ & $\mathrm{X}$ & & & \\
\hline MYBPC3 & Myosin-binding protein $\mathrm{C}$ & $\mathrm{X}$ & $\mathrm{X}$ & $\mathrm{X}$ & & & & \\
\hline МYH6 & $\alpha$-Myosin heavy chain & $\mathrm{X}$ & $\mathrm{X}$ & & & & & $\begin{array}{l}\text { Congenital heart } \\
\text { defects }\end{array}$ \\
\hline MYH7 & $\beta$-Myosin heavy chain & $\mathrm{X}$ & $\mathrm{X}$ & $\mathrm{X}$ & $\mathrm{X}$ & & & $\begin{array}{l}\text { Congenital heart } \\
\text { defects }\end{array}$ \\
\hline MYL2 & Myosin light chain (R) & $\mathrm{X}$ & & & $\mathrm{X}$ & & & \\
\hline MYL3 & Myosin light chain (E) & $\mathrm{X}$ & & & $\mathrm{X}$ & & & \\
\hline MYLK2 & Myosin light chain kinase 2 & $\mathrm{X}$ & & & & & & \\
\hline TNNC1 & Troponin C & $\mathrm{X}$ & $\mathrm{X}$ & & & & & \\
\hline TNNI3 & Troponin I & $\mathrm{X}$ & $\mathrm{X}$ & $\mathrm{X}$ & $\mathrm{X}$ & & & \\
\hline TNNT2 & Troponin T & $\mathrm{X}$ & $\mathrm{X}$ & $\mathrm{X}$ & $\mathrm{X}$ & & & \\
\hline TPMI & $\alpha$-Tropomyosin & $\mathrm{X}$ & $\mathrm{X}$ & $\mathrm{X}$ & $\mathrm{X}$ & & & \\
\hline TTN & Titin & $\mathrm{X}$ & $\mathrm{X}$ & & & $\mathrm{X}$ & & \\
\hline \multicolumn{9}{|l|}{ Z-disc } \\
\hline ACTN2 & $\alpha$-Actinin & $\mathrm{X}$ & $\mathrm{X}$ & & & & & \\
\hline ANKRD1 & $\begin{array}{l}\text { Cardiac ankyrin repeat } \\
\text { protein }\end{array}$ & $\mathrm{X}$ & $\mathrm{X}$ & & & & & $\begin{array}{l}\text { Congenital heart } \\
\text { defects }\end{array}$ \\
\hline$B A G 3$ & $\begin{array}{l}\text { Bcl-2-associated } \\
\text { athanogene } 3\end{array}$ & & $\mathrm{X}$ & & & & & $\begin{array}{l}\text { Myofibrillar } \\
\text { myopathy: } \\
\text { LVH + RCM }\end{array}$ \\
\hline CSRP3 & Muscle LIM protein & $\mathrm{X}$ & $\mathrm{X}$ & & & & & \\
\hline FHL2 & $\begin{array}{l}\text { Four and half LIM } \\
\text { protein-2 }\end{array}$ & & $\mathrm{X}$ & & & & & \\
\hline$L D B 3$ & Cypher/ZASP & $\mathrm{X}$ & $\mathrm{X}$ & $\mathrm{X}$ & & & & \\
\hline MURC & $\begin{array}{l}\text { Muscle-restricted } \\
\text { coiled-coil }\end{array}$ & & $\mathrm{X}$ & & & & & \\
\hline MYOZ2 & Myozenin & $\mathrm{X}$ & & & & & & \\
\hline$M Y P N$ & Myopalladin & & $\mathrm{X}$ & & & & & \\
\hline$N E B L$ & Nebulette & & $\mathrm{X}$ & & & & & \\
\hline$N E X N$ & Nexilin & $\mathrm{X}$ & $\mathrm{X}$ & & & & & \\
\hline TCAP & Telethonin & $\mathrm{X}$ & $\mathrm{X}$ & & & & & \\
\hline$V C L$ & Vinculin & $\mathrm{X}$ & $\mathrm{X}$ & & & & & \\
\hline \multicolumn{9}{|c|}{ Cytoskeleton } \\
\hline DES & Desmin & & $\mathrm{X}$ & & $\mathrm{X}$ & & & $\begin{array}{l}\text { Myofibrillar } \\
\text { myopathy: } \\
\text { ARVC }\end{array}$ \\
\hline$D M D$ & Dystrophin & & $\mathrm{X}$ & & & & & \\
\hline \multicolumn{9}{|c|}{ Sarcolemma/extracellular matrix } \\
\hline$C A V 3$ & Caveolin 3 & $\mathrm{X}$ & & & & & $\mathrm{X}$ & $\begin{array}{l}\text { DCM + skeletal } \\
\text { myopathy }\end{array}$ \\
\hline CHRM2 & $\begin{array}{l}\text { M2-muscarinic } \\
\text { acetylcholine receptor }\end{array}$ & & $\mathrm{X}$ & & & & & \\
\hline DTNA & $\alpha$-Dystrobrevin & & & $\mathrm{X}$ & & & & \\
\hline ILK & Integrin-linked kinase & & $\mathrm{X}$ & & & & & \\
\hline LAMA4 & Laminin- $\alpha 4$ & & $\mathrm{X}$ & & & & & \\
\hline
\end{tabular}


Table 1. Continued

\begin{tabular}{|c|c|c|c|c|c|c|c|c|}
\hline Gene & & $\mathrm{HCM}$ & DCM & LVNC & $\mathrm{RCM}$ & ARVC & $\begin{array}{l}\text { Arrhythmic } \\
\text { syndromes }^{\mathrm{a}}\end{array}$ & Other \\
\hline$S G C B$ & $\beta$-Sarcoglycan & & $\mathrm{X}$ & & & & & \\
\hline SGCD & $\delta$-Sarcoglycan & & $\mathrm{X}$ & & & & & \\
\hline \multicolumn{9}{|c|}{ Desmosome } \\
\hline DSC2 & Desmocollin-2 & & $\mathrm{X}$ & & & $\mathrm{X}$ & & \\
\hline DSG2 & Desmoglein-2 & & $\mathrm{X}$ & & & $\mathrm{X}$ & & \\
\hline$D S P$ & Desmoplakin & & $\mathrm{X}$ & $\mathrm{X}$ & & $\mathrm{X}$ & & \\
\hline JUP & Plakoglobin & & & & & $\mathrm{X}$ & & \\
\hline PKP2 & Plakophilin-2 & & $\mathrm{X}$ & & & $\mathrm{X}$ & & \\
\hline \multicolumn{9}{|l|}{ Nucleus } \\
\hline$E M D$ & Emerin & & $\mathrm{X}$ & & & & & EDMD \\
\hline EYA4 & Eyes absent homolog 4 & & $\mathrm{X}$ & & & & & \\
\hline GATAD1 & $\begin{array}{l}\text { GATA zinc finger domain- } \\
\text { containing protein } 1\end{array}$ & & $\mathrm{X}$ & & & & & \\
\hline LMNA & Lamin A/C & & $\mathrm{X}$ & $\mathrm{X}$ & & & & $\begin{array}{l}\text { EDMD, } \\
\text { extracardiac } \\
\text { disorders }\end{array}$ \\
\hline$N K X 2-5$ & NKX2-5 & & $\mathrm{X}$ & $\mathrm{X}$ & & & & $\begin{array}{l}\text { Congenital heart } \\
\text { defects }\end{array}$ \\
\hline PRDM16 & PR domain-containing 16 & & $\mathrm{X}$ & & & & & \\
\hline RBM20 & RNA-binding protein 20 & & $\mathrm{X}$ & & & & & \\
\hline TMPO & Thymopoietin & & $\mathrm{X}$ & & & & & \\
\hline \multicolumn{9}{|c|}{ Sarcoplasmic reticulum $/ \mathrm{Ca}^{2+}$ channels $^{\mathrm{a}}$} \\
\hline CASQ2 & Calsequestrin 2 & $\mathrm{X}$ & & $\mathrm{X}$ & & & $\mathrm{X}$ & \\
\hline $\mathrm{JPH} 2$ & Junctophilin & $\mathrm{X}$ & & & & & & \\
\hline$P L N$ & Phospholamban & $\mathrm{X}$ & $\mathrm{X}$ & & & & & \\
\hline RYR2 & Ryanodine receptor & & & & & $\mathrm{X}$ & $\mathrm{X}$ & \\
\hline \multicolumn{9}{|c|}{$\mathrm{K}^{+}, \mathrm{Na}^{+}$ion channels ${ }^{\mathrm{a}}$} \\
\hline$A B C C 9$ & $\begin{array}{l}\text { SUR2A subunit, } \mathrm{K}_{\mathrm{ATP}} \\
\text { channel }\end{array}$ & & $\mathrm{X}$ & & & & & \\
\hline SCN5A & Cardiac sodium channel & & $\mathrm{X}$ & $\mathrm{X}$ & & & $\mathrm{X}$ & \\
\hline \multicolumn{9}{|c|}{ Mitochondria } \\
\hline COX15 & $\begin{array}{l}\text { COX15 homolog, } \\
\text { cytochrome } c \text { oxidase } \\
\text { assembly protein }\end{array}$ & & & & & & & Infantile LVH \\
\hline DNAJC19 & TIM14 & & & & & & & $\begin{array}{l}\text { DCMA syndrome: } \\
\text { DCM, LVNC }\end{array}$ \\
\hline SDHA & Succinate dehydrogenase & & & & & & & Neonatal DCM \\
\hline$T A Z$ & Tafazzin & & & & & & & $\begin{array}{l}\text { Barth syndrome: } \\
\text { DCM, LVNC }\end{array}$ \\
\hline \multicolumn{9}{|c|}{ Cytoplasm/transmembrane } \\
\hline CRYAB & $\alpha \beta$-Crystallin & & $\mathrm{X}$ & & & & & \\
\hline FKTN & Fukutin & & $\mathrm{X}$ & & & & & \\
\hline GLA & $\alpha$-Galactosidase & & & & & & & $\begin{array}{l}\text { Fabry disease: } \\
\text { LVH }\end{array}$ \\
\hline LAMP2 & $\begin{array}{l}\text { Lysosomal membrane- } \\
\quad \text { associated } 2\end{array}$ & & & & & & & $\begin{array}{l}\text { Danon disease: } \\
\text { LVH, DCM }\end{array}$ \\
\hline
\end{tabular}


D. Fatkin et al.

Table 1. Continued

\begin{tabular}{|c|c|c|c|c|c|c|c|}
\hline Gene & & $\mathrm{HCM}$ & DCM & LVNC RCM & ARVC & $\begin{array}{l}\text { Arrhythmic } \\
\text { syndromes }^{\text {a }}\end{array}$ & Other \\
\hline MIB1 & Mind bomb homologue 1 & & & $\mathrm{X}$ & & & \\
\hline PRKAG2 & AMPK subunit $\gamma 2$ & & & & & & $\begin{array}{l}\text { Glycogen storage } \\
\text { disease: LVH, } \\
\text { ventricular pre- } \\
\text { excitation }\end{array}$ \\
\hline PSEN1 & Presenilin-1 & & $\mathrm{X}$ & & & & \\
\hline PSEN2 & Presenilin-2 & & $\mathrm{X}$ & & & & \\
\hline TMEM43 & $\begin{array}{l}\text { Transmembrane protein } \\
\quad 43\end{array}$ & & & & $\mathrm{X}$ & & \\
\hline TTR & Transthyretin & & & & & & $\begin{array}{l}\text { Amyloidosis: } \\
\text { LVH, RCM }\end{array}$ \\
\hline YWHAE & $14-3-3 \varepsilon$ & & & $\mathrm{X}$ & & & \\
\hline \multicolumn{8}{|c|}{$\begin{array}{l}\text { ARVC, Arrhythmogenic right ventricular cardiomyopathy; DCM, dilated cardiomyopathy; DCMA, DCM with ataxia; } \\
\text { EDMD, Emery-Dreifuss muscular dystrophy; HCM, hypertrophic cardiomyopathy; LVH, left ventricular hypertrophy; } \\
\text { VNC, left ventricular noncompaction; RCM, restrictive cardiomyopathy. } \\
\text { a Mutations in the following genes encoding ion channels and related proteins have been associated with ventricular } \\
\text { Irrhythmic syndromes but not with other types of ventricular cardiomyopathy: KCNQ1, KCNH2, KCNE1, KCNE2, } \\
\text { KCNE3, KCNJ2, KCNJ5, SCN1B, SCN3B, SCN4B, CACNA1C, CACNA2D1, CACNB2, GDP1L, HCN4, SNTA1, AKAP9. }\end{array}$} \\
\hline
\end{tabular}

\section{Dilated Cardiomyopathy}

DCM is characterized by increased chamber size and impaired systolic contraction of the left and/or right ventricles. In addition to these defining features, there may be a range of additional echocardiographic and ECG abnormalities. Although ventricular wall thickness may be normal or reduced on transthoracic echocardiography, overall left ventricular mass is usually increased. Dilatation of the atria is frequently seen and may result from left ventricular diastolic filling defects, mitral valve regurgitation, and/or atrial myopathy. DCM as a result of any cause may be complicated by progressive heart failure, supraventricular and ventricular arrhythmias, thromboembolic stroke, and sudden death. In genetic forms of DCM, there may be distinctive cardiac or extracardiac features, including conduction-system abnormalities, congenital heart defects, valvular defects, left ventricular noncompaction (LVNC), skeletal myopathy, lipodystrophy, and sensorineural deafness. The differential diagnosis of DCM encompasses a broad range of genetic and acquired factors (Maron et al. 2006). Defining the etiology of DCM has clinical utility because some etiologies-including viral or bacterial infections, drugs, toxins, autoimmune, metabolic, endocrine, or nutritional disorders-are potentially treatable. However, among the $50 \%$ of cases without an identified cause, one in four individuals has a family history of DCM, suggesting an underlying genetic basis (Petretta et al. 2011).

Genetic variants have been associated with sporadic cases of DCM or identified in families that usually show an autosomal-dominant inheritance pattern, with autosomal-recessive or X-linked inheritance in a minority of cases. More than 40 genes have been associated with a predominant clinical phenotype of adultonset DCM, and these encode diverse components of the sarcomere, Z-disc, cytoskeleton, sarcolemma, and nucleus (Table 1). Relatively few mutations have been identified in most of these genes, and the yield of genetic testing has been only $20 \%-30 \%$ (Hershberger and Siegfried 2011; Millat et al. 2011; Teekakirikul et al. 2013; van Spaendonck-Zwarts et al. 2013). One notable exception is the LMNA gene, which causes DCM and conduction-system disease (Fatkin et al. 1999, 2010). Because of its distinctive phenotype, the LMNA gene has been frequently screened, and this has yielded high num- 
bers of mutations. Recently, truncating mutations in the TTN gene that encodes the giant protein titin were identified in $25 \%$ of cases of familial DCM and 18\% of sporadic DCM cases (Herman et al. 2012). Although these findings have yet to be confirmed in independent patient cohorts, these results point to the TTN gene being the most common cause of familial DCM, and inclusion of this gene in genetic testing panels should substantially increase the yield of positive results.

\section{Arrhythmogenic Right Ventricular Cardiomyopathy}

ARVC is characterized histologically by progressive myocyte loss and fibrofatty replacement of the right ventricle, with left ventricular involvement in up to $75 \%$ of cases. There can be a wide range of phenotypical features, including ventricular tachyarrhythmias, syncope, or sudden death, and segmental or global chamber dilatation and contractile defects. The clinical diagnosis of ARVC can be challenging, and sets of major and minor criteria have been devised by task forces of international experts that take into account structural and functional abnormalities, tissue characterizations, ECG abnormalities, arrhythmias, and family history (McKenna et al. 1994; Marcus et al. 2010). Because of the high frequency of biventricular abnormalities, clinical differentiation of individuals with ARVC from those with DCM is difficult.

Families with ARVC have generally shown autosomal-dominant inheritance patterns. ARVC has also been reported as an autosomal-recessive disorder in two syndromes: Naxos syndrome, which is associated with woolly hair and palmarplantar keratoderma, and Carvajal syndrome, associated with prominent left ventricular as well as skin involvement. Mutations in nine genes have been associated with ARVC with varying levels of evidence; five of these encode the desmosomal proteins, plakophilin2, plakoglobin, desmoplakin, desmocollin, and desmoglein-2 (Teekakirikul et al. 2013). Approximately $50 \%$ of ARVC cases have a desmosomal gene mutation, most commonly ( 40\%) in the plakophilin-2 gene (van Tintelen et al.
2006; den Haan et al. 2009). Desmosomal gene mutations have also been identified in $\sim 5 \%$ of subjects with a clinical diagnosis of DCM (Elliott et al. 2010). A small number of mutations in genes encoding the nondesmosomal proteins, transmembrane protein 43 , transforming growth factor $\beta 3$, cardiac ryanodine receptor, and titin have been associated with ARVC.

\section{Left Ventricular Noncompaction}

During normal heart development, thick trabeculations form in the early embryonic ventricle, and these subsequently compress to become the endocardium. LVNC is considered to be a developmental defect in which trabecular compaction fails to occur. The resulting noncompacted endocardium adjacent to compacted epicardium gives rise to a two-layered appearance of the myocardial wall that is detectable on imaging modalities such as transthoracic echocardiography or magnetic resonance imaging. These changes also result in deep intertrabecular sinusoidal recesses that have a predilection for blood clot formation. LVNC is usually detected as an asymptomatic finding during cardiac imaging and may occur in isolation or in association with other congenital heart abnormalities. The trabecular thickening in LVNC may be difficult to distinguish from left ventricular hypertrophy that results from other causes, and the differential diagnosis includes HCM, hypertensive cardiomyopathy, endocardial fibroelastosis, apical thrombus, and tumors (Oechslin and Jenni 2011). Left ventricular systolic function can deteriorate over time, and patients with LVNC often experience heart failure, ventricular arrhythmias, or thromboembolic events. LVNC may be sporadic or familial, with autosomal-dominant, autosomal-recessive, and Xlinked inheritance reported. Mutations in sarcomere protein genes have been found in up to $50 \%$ of LVNC cases, with the majority of variants in the MYH7 gene (Hoedemaekers et al. 2007; Klaassen et al. 2008; Pantazis and Elliott 2009; Probst et al. 2011). Mutations in Z-disc, cytoskeletal, and mitochondrial genes have also been found (Table 1). Deletion and loss-offunction dominant mutations in PRDM16, a 
D. Fatkin et al.

gene of unknown function(s), have also been identified to cause LVNC that occurs in isolation or in the context of the chromosome 1 p36 deletion syndrome (Arndt et al. 2013).

\section{Restrictive Cardiomyopathy}

RCM is a rare cardiomyopathy associated with impaired ventricular diastolic filling and increased end-diastolic pressure, which results in normal or reduced ventricular dimensions and biatrial dilatation. Ventricular wall thickness and systolic function are initially normal, although systolic dysfunction and heart failure may develop with increasing age. The overall prognosis in RCM is poor, especially in pediatric cases, and heart transplantation is often required. RCM can occur as a primary cardiomyopathy with a genetic etiology or occur secondary to infiltrative or systemic disorders such as amyloidosis and sarcoidosis. Mutations in seven sarcomere protein genes (Table 1), as well as in DES, encoding the cytoskeletal protein desmin, have been found in sporadic cases and families with RCM (Parvatiyar et al. 2010a; SenChowdry et al. 2010; Caleshu et al. 2011). The differential diagnosis of RCM includes HCM, which can also manifest with restrictive diastolic filling defects and atrial dilatation. The high prevalence of sarcomere protein gene mutations does raise the question as to whether RCM and $\mathrm{HCM}$ are truly distinctive disorders or represent different points along a spectrum of left ventricular diastolic dysfunction. Mixed RCM and HCM phenotypes frequently coexist in the same families, and the relatively more severe and early onset of disease in many RCM cases may be attributed to a higher "dose" of mutant protein associated with homozygous mutations or compound mutations, some of which may occur de novo (Sen-Chowdry et al. 2010; Caleshu et al. 2011; Pinto et al. 2011). For example, Caleshu et al. (2011) identified one index case that presented with RCM and severe heart failure requiring cardiac transplantation. She was found to be homozygous for an MYL3 variant and heterozygous for an MYL2 variant. Her mother was heterozygous for both mutations and clinically unaffected. A second index case with RCM was homozygous for a TPMI variant. Both parents were heterozygous carriers of this variant, with the father having a diagnosis of HCM. On a mechanistic level, both RCM and HCM have been associated with increased myofilament calcium sensitivity with varying effects on ATPase activity (Parvatiyar et al. 2010b; Willat et al. 2010; Pinto et al. 2011)

\section{Arrhythmic Syndromes}

A number of ventricular arrhythmic syndromes, collectively referred to as "ion channelopathies," have been associated with mutations in genes encoding cardiac sodium, potassium, and calcium channels. These disorders include long QT syndrome, short QT syndrome, Brugada syndrome, catecholaminergic polymorphic ventricular tachycardia, and sudden unexplained nocturnal death syndrome. The characteristics of each of these arrhythmias have been reviewed elsewhere and include ventricular tachycardia, ventricular fibrillation, and death (Cerrone et al. 2012; Webster and Berul 2013). Variants in some of the same ion channel genes have been identified in patients with the "structural" cardiomyopathies, DCM, ARVC, and LVNC, in which ventricular arrhythmias often feature prominently (Tiso et al. 2001; Hershberger et al. 2008; Shan et al. 2008; McNair et al. 2011; Mann et al. 2012).

\section{Overlapping Phenotypes, Overlapping Genes}

The increased knowledge base of genetic causes of cardiomyopathies and longitudinal followup of affected individuals have led to the recognition that there is substantial overlap not only in phenotypical features but also in molecular etiology. Some phenotypical manifestations (increased cardiac mass, contractile dysfunction, arrhythmias, and sudden death) are common to all cardiomyopathy subtypes. Moreover, mutations in the same gene can cause different cardiomyopathies. For example, mutations in the MYH7 gene have been associated with HCM (Geisterfer-Lowrance et al. 1990), DCM (Kamisago et al. 2000), LVNC (Hoedemaekers et al. 2007; Vermeer et al. 2013), and RCM 
(Karam et al. 2008). These observations raise the question of how distinctive the cardiomyopathies really are, and how the phenotypical differences and commonalities can be reconciled at a mechanistic level.

Detailed functional characterizations that have been performed on a few pathogenic mutations provide plausible links to myocardial dysfunction. For example, MYH7 mutations that cause HCM (R403Q) and DCM (F764L or S532P) have reciprocal (increased or decreased, respectively) effects on force production by the sarcomere (Schmitt et al. 2006; Debold et al. 2007; Chuan et al. 2012). Secondary responses triggered by these mutations may be similar (e.g., increased energy utilization, re-expression of fetal genes), whereas other responses, presumably the unidentified signals that drive cardiac remodeling along dilated or hypertrophic pathways, are different. Delineation of these signals will be critical to fully understand genotype-phenotype relationships. The considerable genetic heterogeneity of cardiomyopathies poses additional questions. How do mutations in LMNA (Fatkin et al. 1999) or PLN (Schmitt et al. 2003), which encode, respectively, a nuclear membrane protein and the physiological inhibitor of the sarcoplasmic reticulum $\mathrm{Ca}^{2+}$ ATPase, or in sarcomere protein genes, for example, TTN, MYH7, and ACTC1 (McNally et al. 2013), produce the overlapping phenotype of DCM? Are there multiple mechanisms by which DCM can emerge, or do mutations in molecules with disparate functions converge onto a final common pathway?

\section{FROM GENOME TO PHENOTYPE}

Sequencing of the entire human genome is now available and affordable, and next-generation sequencing technologies have already facilitated the discovery of genetic defects responsible for several rare disorders (Choi et al. 2009; Ng et al. 2010; Worthey et al. 2011). Because diseasecausative variants are enriched in the $1 \%$ of the human genome that contains protein-coding sequences, there has been substantial interest in evaluating these regions using whole-exome sequencing (WES). Databases of whole-genome and WES sequences obtained from many thousands of individuals in large-scale initiatives, such as the 1000 Genomes Project and the NHLBI-funded Exome Sequencing Project (ESP), are documenting the extent and range of genetic variation within populations of varying racial background and have yielded some surprising results. In particular, WES studies have revealed a staggering extent of personal genetic variation with about 20,000 single nucleotide polymorphisms (SNPs) identified in individual European samples and about 24,000 in African American samples (Bamshad et al. 2011).

\section{An Emerging Conundrum: Novel Functionally Deleterious Variants Are Present in the General Population}

Several recent studies that have evaluated variation in cardiomyopathy genes in sequence databases have made an important observation. A substantial number of individuals in the general population carry variants that meet many of the conventional criteria used to define pathogenic variants in disease cohorts, including novelty, high-impact variant type (nonsense, frameshift insertion/deletion, loss or gain of splice donor or acceptor sites, etc.), and predicted or validated protein-altering effects. These observations prompt reevaluation of the criteria for pathogenicity and indicate that single novel missense or loss-of-function variants identified in a few subjects with cardiomyopathy can no longer be assumed to be disease causing.

Variant novelty has been thought to be an important factor, and many of the gene variants that have been considered responsible for cardiomyopathies have been "private" mutations seen only in a single family. With insights gained from sequence data in many thousands of individuals in the general population, it has now become apparent that, in fact, a substantial proportion of human coding sequence variants are rare. A good example of this was provided in the data reported by Pan et al. (2012), who looked at SNPs in coding regions of 46 cardiomyopathy genes in more than 5000 individuals 
D. Fatkin et al.

in the ESP database and found that 9103 (91\%) of the 9974 total variants were rare (minor allele frequency $<1 \%)$ and that $5448(60 \%)$ of these were novel and seen only in one individual. In traditional Sanger-sequencing studies of selected candidate genes, any single high-impact variants identified have been assumed to be pathogenic. However, bioinformatics analyses of next-generation sequencing outputs are revealing that the average human genome contains more than 100 of these types of variants, with at least 20 encoded proteins being completely inactivated (Bamshad et al. 2011; MacArthur et al. 2012). Furthermore, the distribution of rare deleterious variants varies significantly among different racial and ethnic ancestries (Fu et al. 2013).

There are now increasing numbers of examples where specific variants reported in the literature to be causative for cardiomyopathy have subsequently been identified in population databases. Norton et al. (2012) looked at 197 rare variants associated with DCM and found that $33(16.8 \%)$ were present in the ESP database. Similarly, Pan et al. (2012) found that four of $46(8.7 \%)$ reported pathogenic variants in the MYH7, MYBPC3, and TNNT2 genes were present in the ESP database. Golbus et al. (2012) evaluated known and predicted pathogenic variants in the MYH7, MYBPC3, and TTN genes in 1092 individuals in the 1000 Genomes Project database. Twenty-one rare or low-frequency protein-altering variants (missense, nonsense, splice site) were present in MYH7 and 22 in MYBPC3, with 700 protein-altering variants in TTN. Twenty-two SNPs in these three genes were present in the Human Genome Mutation database, a comprehensive catalog of diseaseassociated mutations and in the 1000 Genomes Project database. Several variants in desmosomal genes that were initially reported as disease causing in ARVC cohorts have similarly been identified in general population control subjects (Milting and Klauke 2008; Christensen et al. 2010).

Do these reports highlight a disturbing prevalence of false-positive disease mutations, or are there other explanations? A limitation of both the 1000 Genomes Project and ESP data- bases is that there is a lack of phenotype information, raising the possible explanation that individuals with asymptomatic cardiomyopathy (or other diseases) and/or clinically undiagnosed disease are included in these cohorts. However, Bick et al. (2012) sequenced eight sarcomere protein genes in 3600 individuals from the Framingham Heart Study (FHS, European American) and the Jackson Heart Study (JHS, African American) cohorts, for which there are detailed clinical cardiovascular phenotype data, which for many FHS participants spans many decades. Among these cohorts, $11.2 \%$ individuals had rare, protein-altering variants: 14 in 1637 FHS participants and eight in 1963 JHS participants had been reported in the literature as likely pathogenic. The overall prevalence of likely pathogenic variants was $0.6 \%$, which is approximately twice the estimated prevalence of HCM. Review of echocardiographic results indicated that only four of the 22 variant carriers had undetected HCM. In addition to identifying a subset of individuals with undiagnosed HCM, the results of Bick et al. (2012) show that an overall phenotypical impact of rare sarcomere protein variants and individuals who carried these variants had an increased long-term risk of left ventricular dilatation and adverse cardiovascular events.

\section{New Genetic Models}

Genetic studies in cohorts of patients with cardiomyopathy have an inherent ascertainment bias that may lead to potentially erroneous conclusions about the disease causality of some variants. Next-generation sequencing studies provide an expanded perspective and the opportunity to generate new genetic models that take into account each individual's total burden of genetic variants. Although Mendelian inheritance still indicates the predominant effect of a single mutation, inclusion of genomic information from affected patients and the healthy population can improve this model by excluding false positives and accounting for phenotypic variation among patients with a shared pathogenic mutation. In families with a Mendelian disorder, there is likely to be only one rare var- 
iant with a large functional effect that is primarily responsible for disease. However, the demonstration that a rare variant is absent from small cohorts of healthy controls, alters a conserved amino acid residue, and has predicted or demonstrable protein-altering effects is no longer sufficient evidence for disease causation, in particular, when genome databases show a population prevalence of comparable deleterious variants that exceed the disease prevalence. In contrast, the addition of genetic data such as statistically significant cosegregation within a large family, identification of additional deleterious variants in the same gene from multiple affected families, and functional recapitulation of the phenotype in an animal model should reduce false-positive conclusions about causality. In such families, gene-based diagnosis should be quite accurate. Incorporating genomic data, particularly on functionally related molecules and within protein networks, should improve insights into modifiers that influence phenotype expression. The presence of double and multiple pathogenic cardiomyopathy mutations is known to account for intrafamilial differences in disease onset and severity (Richard et al. 2003; Girolami et al. 2010; Saltzman et al. 2010), but the substantial numbers of unique or rare variants with predicted functional consequences in every person provides the opportunity to fully explore genetic modifiers of disease. Specific and cumulative genomic variation in molecules that may enhance or attenuate the consequences of an inherited pathogenic mutation warrants consideration. An extension of these considerations is that some cardiomyopathies might reflect the collective effects of multiple genetic variants rather than any single dominant mutation. This model would be reflected by non-Mendelian inheritance patterns in families. Researchers and clinicians alike are now confronted by the need to take global burdens of genetic variation into consideration, but these new genetic paradigms will be difficult to test because functional characterization of every variant will be impractical and different variant combinations may have additive, synergistic, or epistatic effects. New parameters such as composite genetic risk scores will need to be devised, and these will need to be related to sensitive, readily measurable functional end points.

\section{From Simplicity to Complexity: New Disease Paradigms}

The cardiomyopathy disease genes are often grouped to define potentially unifying phenotype-specific mechanistic pathways. Hence, HCM has been termed a "disease of the sarcomere," DCM a "disease of the cytoskeleton," and ARVC a "disease of the desmosome." These simplistic concepts of disease pathogenesis have their limitations, particularly because a single disease gene may have several biological functions, subcellular locations, and phenotypes, and new disease genes that do not conform to these groupings continue to be discovered. In the light of personal genomic data, new models that incorporate multiple genetic variants potentially affecting diverse aspects of cardiomyocyte structure and function need to be considered.

Genetic variation is only part of the story in cardiomyopathies, however; and over recent years, it has been become apparent that there are numerous factors affecting gene expression and protein function that could determine how each gene mutation is manifested. These contextual factors may be indirect effects of the gene mutations or attributable to the development of cardiomyopathy or comorbidities (Fig. 1). These changes could have an impact on the cardiomyopathy disease genes and encoded proteins, interacting partner proteins, or the myocardial contractile milieu, with net functional sequelae.

Many factors intrinsic and extrinsic to the cardiomyocyte are now known to influence gene expression profiles. Some of the most exciting recent discoveries relate to epigenetic mechanisms that regulate gene expression, including DNA methylation, histone modifications, ATPdependent chromatin remodeling, and noncoding RNAs, including lincRNAs and microRNAs (Leach et al. 2010; Movassagh et al. 2011; Chang and Brunear 2012; Schonrock et al. 2012; Papait et al. 2013; Udali et al. 2013). MicroRNAs 
D. Fatkin et al.
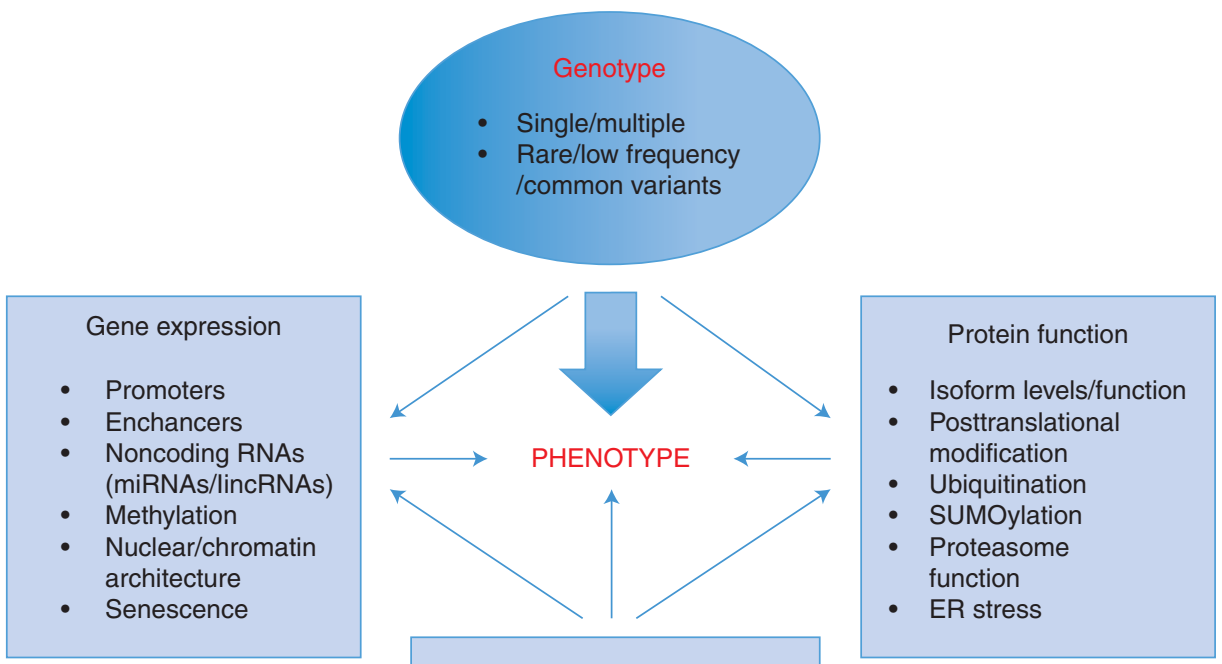

Cardiac environment

- Neurohumoral factors

- Autonomic nervous system

- Ischemia

- Hemodynamic load

- Energetics/mitochondria

- Infection

- Inflammation

- Immune function

- Drugs, alcoho

- Comorbidities

Figure 1. Schematic showing potential roles of genetics and other factors that are intrinsic and extrinsic to the cardiomyocyte as determinants of cardiomyopathy phenotype.

are small ( $\sim 22$ nucleotide) noncoding RNAs that bind to the $3^{\prime}$-untranslated regions of target mRNAs and typically reduce mRNA levels by inhibiting translation or stimulating mRNA decay. Each microRNA has multiple mRNA targets, and there are estimated to be more than 2000 microRNAs that collectively regulate most protein-coding genes. Since the first report by van Rooij et al. (2006), there has been an explosion of interest in cardiac microRNAs, with several hundred papers describing their roles in cardiac development, adult heart function, and heart diseases (Thum et al. 2007; Divakaran and Mann 2008; Rao et al. 2009; Mendell and Olson 2012). Relatively few genetic variants that alter microRNA function in the heart have been reported. In one study, a human miR-499 variant identified in an unselected population of 2600 individuals was modeled in transgenic mice. Whereas wild-type miR-499 transgenic mice developed progressive DCM, the mutant mice had more favorable mRNA expression profiles and less severe cardiac dysfunction (Dorn et al. 2012). In another study in an arrhythmia cohort, a variant in the MIR133A2 gene that encodes the cardiac microRNA miR-133a was shown to alter duplex processing and the mRNA target spectrum (Ohanian et al. 2013). The role of epigenetic factors, including microRNAs, has not yet been extensively evaluated in the inherited cardiomyopathies, and this promises to be a fruitful area for further research.

Protein activation and turnover are determinants of normal cardiomyocyte function and can be altered by specific gene mutations or generalized disorders. For example, a mutation in the cardiac transcription factor NKX2-5 identified in a family with congenital heart dis- 
ease and DCM was shown to have reduced DNA-binding affinity, and there was also increased expression of mutant protein because of reduced degradation by the ubiquitin-proteasome system (Costa et al. 2013). Dysfunction of the endoplasmic reticulum can occur in a variety of pathological conditions and has diverse effects on protein synthesis, degradation, trafficking, and posttranslational modification (Groenendyk et al. 2010). Posttranslational modifications are important for the activity of many proteins, including the giant sarcomere protein titin. The mechanical properties of titin's cardiac-specific N2B spring and the PEVK region are altered by phosphorylation, which is, in turn, modulated by $\beta$-adrenergic stimulation and heart failure (Hidalgo and Granzier 2013). The relative levels of expression of titin isoforms containing different N2A, $\mathrm{N} 2 \mathrm{~B}$, and PEVK sequences determine passive stiffness of cardiomyocytes, and these ratios can be altered in heart failure and by mutations in $R B M 20$, a recently described DCM disease gene (Guo et al. 2012; LeWinter and Granzier 2013).

Taken together, these observations indicate a need to look beyond the single variant as an explanation for pathogenesis of cardiomyopathies and shift toward more complex models that take into consideration the actions and interactions of multiple genetic, epigenetic, and environmental factors (Fig. 1). The collective burden of all these influences on myocardial function can be expected to determine the cardiac phenotype.

\section{FUNCTIONAL EVALUATION OF GENETIC VARIANTS}

\section{Induced Pluripotent Stem (iPS) Cells}

The functional consequences of single genetic variants are often evaluated in transfected cells. Although useful, these types of in vitro experiments are unable to take into account the effects of background genetic variation or the plethora of factors that affect protein function in the beating heart. The landmark discovery that somatic cells derived from patient tissue sam- ples can be reprogrammed to become induced pluripotent stem (iPS) cells that can be subsequently differentiated into mature cells of interest, such as cardiomyocytes, generated enormous interest worldwide and for the first time permitted patient-specific functional evaluation of genetic variants and responses to therapy (Takahashi and Yamanaka 2006). Several human cardiomyopathy and arrhythmia mutations have already been modeled in iPS cells; however, there remain substantial technical challenges to fully differentiate iPS cells into adult cardiomyocytes. The immaturity of iPSderived cardiomyocytes can have significant functional implications. For example, in murine and human iPS cells, t-tubules and associated proteins are typically absent, and this results in non-uniform propagation of calcium transients and incomplete electrical coupling of cells (Lieu et al. 2009). iPS cells are also not subjected to the hemodynamic load that critically impacts the function of in vivo myocytes. Although many features of the human cardiomyopathy phenotypes have been recapitulated, relatively few novel mechanistic insights have as yet been gained into how different mutations impact phenotype (Moretti et al. 2010; Itzhaki et al. 2011; Sun et al. 2012; Kim et al. 2013; Knollman 2013; Priori et al. 2013). Nevertheless, with further refinements of culturing techniques and emerging tools for genome editing, analyses of isogenic iPS cells may well become a valuable asset for gene variant evaluation.

\section{Zebrafish as a Model for Cardiovascular Disease}

Genetically modified mice have been the animal model of choice to evaluate in vivo effects of human gene mutations. Murine models have several limitations, however, including the time and expense of generating, breeding, and aging adequate numbers of experimental mice. Zebrafish are rapidly gaining popularity as a model organism because they are easy to breed, have rapid development and numerous progeny, and genetic manipulation can be readily achieved (Lieschke and Currie 2007; Dahme et al. 2009; Santoriello and Zon 2012; Verkerk and Remme 
D. Fatkin et al.

2012). Two distinctive properties of zebrafish during the first weeks of life are their transparency, which enables heart development and function to be directly observed in real time, and their independence from a functioning circulatory system for oxygen supply to the tissues. Although the zebrafish heart has only two chambers, many aspects of cardiac physiology are similar to that of humans (Milan et al. 2006; Milan and MacRae 2008; Verkerk and Remme 2012). There are some notable anatomical differences, however, such as the lack of coronary arteries and pulmonary vasculature. Although a majority of human genes have zebrafish orthologs, a genomic duplication event that occurred during teleost evolution has resulted in duplicate pairs of many zebrafish genes, which is an important consideration for gene knockdown experiments. Naturally occurring or chemically induced zebrafish mutations that result in cardiac phenotypes can be studied to identify new candidate genes for human cardiomyopathies and arrhythmias (Fig. 2A) (Bendig et al. 2006; Dahme et al. 2009). Conversely, transient or sustained knockdown of zebrafish genes using morpholino-modified antisense oligonucleotides or new gene-editing techniques such as transcription activator-like effector nucleases (TALENs), respectively, can be used to study the effects of genes with no known cardiac functions in which variants may be identified by WES or other sequencing methods (Sander et al. 2011; Santoriello and Zon 2012; Arndt et al. 2013). Finally, human gene variants can be modeled using transgenic zebrafish (Fig. 2B) (Huttner et al. 2013). These models will be invaluable for elucidating molecular mechanisms of disease and for evaluating therapies.
A
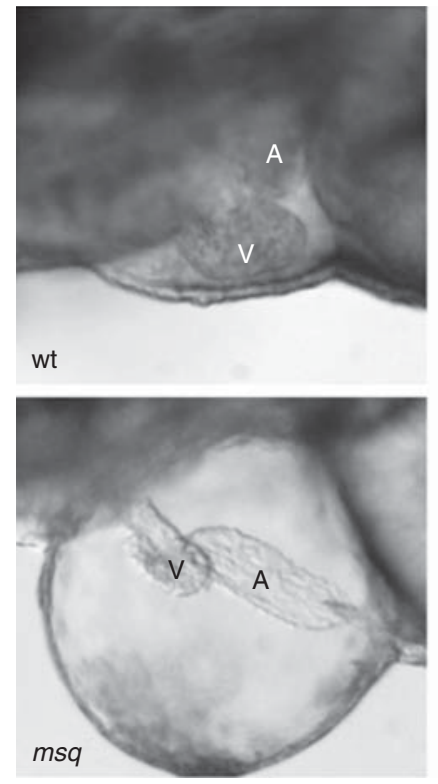

B

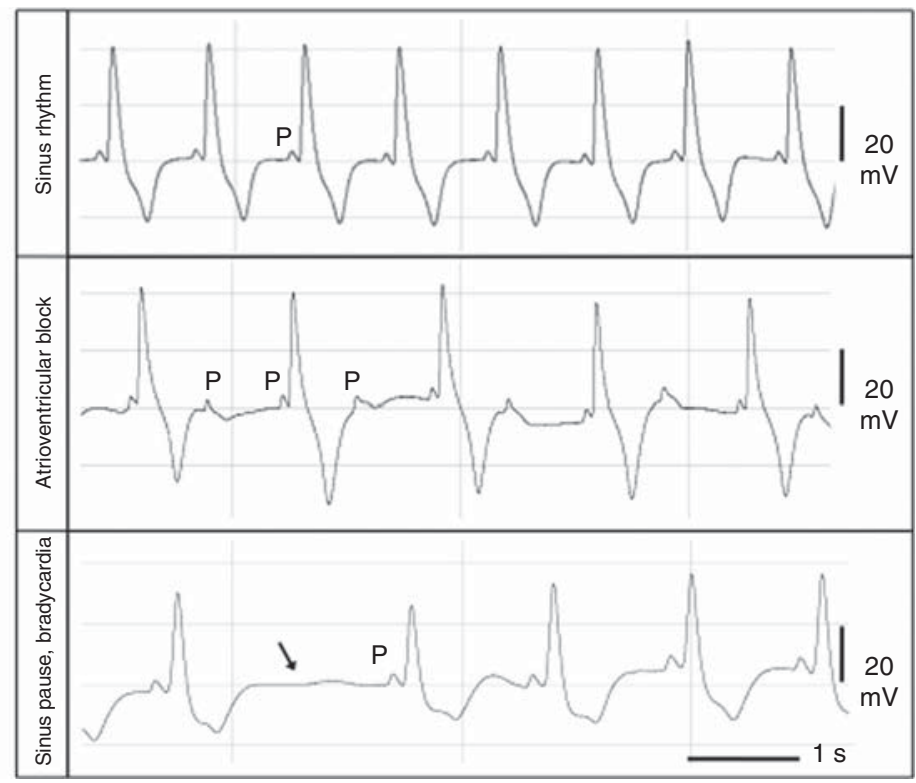

Figure 2. Effects of cardiac gene mutations in zebrafish. (A) Lateral view of embryonic zebrafish hearts at $3 \mathrm{~d}$ postfertilization. (Top panel) Wild-type (wt) heart; (lower panel) heart of a mainsqueeze ( $m s q$ ) mutant showing pericardial edema because of loss of ventricular contractility. A, atrium; V, ventricle. Genetic studies of the ENUgenerated msq mutant identified an L308P variant in the integrin-linked kinase (ilk) gene (Bendig et al. 2006). ILK mutations have subsequently been associated with human DCM. (B) ECG tracings from anesthetized adult zebrafish. (Top panel) Normal sinus rhythm in a wild-type zebrafish. (Middle and lower panels) 2:1 Atrioventricular block and sinus bradycardia with pauses, respectively, in transgenic zebrafish expressing the human SCN5A D1275N mutation (Huttner et al. 2013). 


\section{CLINICAL IMPLICATIONS}

\section{Genetic Testing}

Current expert consensus guidelines for genetic testing in cardiomyopathies have been formulated with the objectives of establishing the etiology of disease in index cases and genotyping asymptomatic relatives to ascertain those at risk of developing disease (Hershberger et al. 2009). Targeted sequencing tests of the most common disease genes for each of the cardiomyopathies have been available for some time in diagnostic laboratories worldwide, and the relative cost, yield, and reliability of these tests in comparison to WES for clinical use is a subject of current debate (Sikkema-Raddatz et al. 2013; Teekakirikul et al. 2013). A major challenge for both genetic testing techniques is data analysis and interpretation of the significance of variants. Given the increasing appreciation of the frequency of novel and functionally deleterious variants in the general population, increasingly robust evidence will be required to be confident that any particular variant is truly disease causing, and there will undoubtedly be an exponential rise in the numbers of "variants of unknown significance." Caution is also required in giving negative results to asymptomatic family members and releasing them from follow-up, because the absence of a one-family-gene variant does not necessarily preclude the presence of additional potentially deleterious variants in other genes.

\section{Genetics as a Guide to Therapy?}

Treatment guidelines for heart failure and arrhythmias in cardiomyopathies are similar to those for nongenetic causes of these disorders. There are no specific therapies in current clinical use that change gene mutations. However, the R222Q SCN5A mutation has recently provided a proof-of-principle example in which the effect of a mutant protein can be directly targeted. This variant has been reported in several families with DCM and complex ventricular arrhythmias and has been shown to have an activating effect on cardiac sodium channels (Hershberger et al. 2008; McNair et al. 2011;
Mann et al. 2012). Treatment of affected family members with drugs that have sodium-channel-blocking properties markedly reduced the numbers of ventricular ectopic beats and improved ventricular contractile function (Mann et al. 2012). Various therapies directed toward reversing biological processes downstream from the initiating genetic trigger have been shown to be effective in murine cardiomyopathy models, and some of these have been evaluated subsequently in human clinical trials. Examples of this include treatment with L-type calcium channel inhibitors, HMG CoA reductase inhibitors, antioxidants in HCM models, and $\beta$ blockers and extracellular signal-regulated kinase (ERK) inhibitors in DCM models (Patel et al. 2001; Semsarian et al. 2002; Lombardi et al. 2009; Muchir et al. 2009; Chandar et al. 2010; Yeoh et al. 2011). Other new approaches to therapy that are currently under investigation include reversal of microRNA effects with antagomirs, and stem-cell therapies. It is envisaged that the wealth of genetic data provided by whole genome and WES will reveal tractable targets for novel drug therapies. The ultimate goal of genetics studies is to enable personalized approaches to diagnosis, treatment, and prevention. This will require high-throughput bioinformatics analysis, identification and validation of actionable variants, and prospective clinical assessment.

\section{CONCLUDING REMARKS}

These are exciting times in cardiovascular genetics when genomic sequencing on an unprecedented scale promises to revolutionize understanding of cardiomyopathy pathogenesis as well as approaches to investigation and treatment. New ways to rapidly assess the functional significance of variants singly, and in combination, are required. Several fundamental questions need to be addressed, including why patients with the same phenotype have different genotypes, and why those with the same genotype develop different phenotypes. The answers to this question will no doubt need to take into account each person's entire profile of rare and common genetic variants as well as epigenetic 
D. Fatkin et al.

and environmental factors, and future strategies for diagnosis, early detection, and management of cardiomyopathy may need to focus on endpoint myocardial functional defects.

\section{ACKNOWLEDGMENTS}

We thank Inken Huttner for zebrafish cardiac images. We are supported by grants from the National Health and Medical Research Council of Australia (APP1025008, 573732) and the Harvard Club of Australia Foundation (to D.F.), the Howard Hughes Medical Institute (to C.E.S.), National Institutes of Health (to J.G.S.), and the Leducq Foundation (to C.E.S. and J.G.S.).

\section{REFERENCES}

Arad M, Maron BJ, Gorham JM, Johnson WH Jr, Saul JP Perez-Atayde AR, Spirito P, Wright GB, Kanter RJ, Seidman CE, et al. 2005. Glycogen storage diseases presenting as hypertrophic cardiomyopathy. $N$ Engl J Med 352: 362-372.

Arndt AK, Schafer S, Drenckhahn JD, Sabeh MK, Plovie ER, Caliebe A, Klopocki E, Musso G, Werdich AA, Kalwa H, et al. 2013. Fine mapping of the 1p36 deletion syndrome identifies mutation of PRDM16 as a cause of cardiomyopathy. Am J Hum Genet 93: 1-11.

Bamshad MJ, Ng SB, Bigham AW, Tabor HK, Emond MJ, Nickerson DA, Shendure J. 2011. Exome sequencing as a tool for Mendelian disease gene discovery. Nat Rev Genet 12: $745-755$.

Bendig G, Grimmler M, Huttner IG, Wessels G, Dahme T, Just S, Trano N, Katus HA, Fishman MC, Rottbauer W. 2006. Integrin-linked kinase, a novel component of the cardiac mechanical stretch sensor, controls contractility in the zebrafish heart. Genes Dev 20: 2361-2372.

Bick AG, Flannick J, Ito K, Cheng S, Vasan RS, Parfenov MG, Herman DS, DePalma SR, Gupta N, Gabriel SB, et al. 2012. Burden of rare sarcomeric gene variants in the Framingham and Jackson Heart Study cohorts. Am J Hum Genet 91: 513-519.

Caleshu C, Sakhuja R, Nussbaum RL, Schiller NB, Ursell PC, Eng C, De Marco T, McGlothlin D, Burchard EG, Rame JE. 2011. Furthering the link between sarcomere and primary cardiomyopathies: Restrictive cardiomyopathy associated with multiple mutations in genes previously associated with hypertrophic or dilated cardiomyopathy. Am J Med Genet 155A: 2229-2235.

Cerrone M, Napolitano C, Priori SG. 2012. Genetics of ionchannel disorders. Curr Opin Cardiol 27: 242-252.

Chandar S, Yeo LS, Leimena C, Tan JC, Xiao XH, NikolovaKrstevski N, Yasuoka Y, Gardiner-Garden M, Wu J, Kesteven S, et al. 2010. Effects of mechanical stress and carvedilol in lamin A/C-deficient dilated cardiomyopathy. Circ Res 106: 573-582.
Chang CP, Brunear BG. 2012. Epigenetics and cardiovascular development. Annu Rev Physiol 74: 41-68.

Choi M, Scholl UI, Ji W, Liu T, Tikhonova IR, Zumbo P, Nayir A, Bakkaloglu A, Ozen S, Sanjad S, et al. 2009. Genetic diagnosis by whole exome capture and massively parallel DNA sequencing. Proc Natl Acad Sci 106: 1909619101.

Christensen AH, Benn M, Tybjaerg-Hansen A, Haunso S, Svendsen JH. 2010. Missense variants in plakophilin-2 in arrhythmogenic right ventricular cardiomyopathy patients: Disease-causing or innocent bystanders? Cardiology 115: 148-154.

Chuan P, Sivaramakrishnan S, Ashley EA, Spudich JP. 2012. Cell-intrinsic functional effects of the $\alpha$-cardiac myosin Arg-403-Gln mutation in familial hypertrophic cardiomyopathy. Biophys J 102: 2782-2790.

Costa MW, Guo G, Wolstein O, Vale M, Castro ML, Wang L, Otway R, Riek P, Cochrane N, Furtado M, et al. 2013. Functional characterization of a novel mutation in NKX2-5 associated with congenital heart disease and dilated cardiomyopathy. Circ Cardiovasc Genet 6: 238-247.

Dahme T, Katus HA, Rottbauer W. 2009. Fishing for the genetic basis of cardiovascular disease. Dis Model Mech 2: $18-22$.

Debold EP, Schmitt JP, Patlak JB, Beck SE, Moore JR, Seidman JG, Seidman CE, Warshaw DM. 2007. Hypertrophic and dilated cardiomyopathy mutations differentially affect the molecular force generation of mouse cardiac $\alpha$ myosin in the laser trap assay. Am J Physiol Heart Circ Physiol 293: H284-H291.

den Haan AD, Tan BY, Zikusoka MN, Llado LI, Jain R, Daly A, Tichnell C, James C, Amat-Alarcon N, Abraham T, et al. 2009. Comprehensive desmosome mutation analysis in North Americans with arrhythmogenic right ventricular dysplasia/cardiomyopathy. Circ Cardiovasc Genet 2: 428-435.

Divakaran V, Mann DL. 2008. The emerging role of microRNAs in cardiac remodelling and heart failure. Circ Res 103: $1072-1083$

Dorn GW II, Matkovich SJ, Eschenbacher WH, Zhang Y. 2012. A human $3^{\prime}$ miR-499 mutation alters cardiac mRNA targeting and function. Circ Res 110: 958-967.

Elliott P, O’Mahony C, Syrris P, Evans A, Sorensen CR, Sheppard MN, Carr-White G, Pantazis A, McKenna W. 2010. Prevalence of desmosomal protein gene mutations in patients with dilated cardiomyopathy. Circ Cardiovasc Genet 3: 314-322.

Fatkin D, MacRae C, Sasaki T, Wolff MR, Porcu M, Frenneaux M, Atherton J, Muehle G, Vidaillet HJ, Spudich S, et al. 1999. Missense mutations in the rod domain of the lamin A/C gene as causes of dilated cardiomyopathy and conduction system disease. N Engl J Med 341: 17151724.

Fatkin D, Otway R, Richmond Z. 2010. Genetics of dilated cardiomyopathy. Heart Fail Clin 6: 129-140.

Fu W, O’Connor TD, Jun G, Kang HM, Abecasis G, Leal SM, Gabriel S, Rieder MJ, Altshuler D, Shendure J, et al. 2013. Analysis of 6,515 exomes reveals the recent origin of most human protein-coding variants. Nature 493: 216-220.

Geisterfer-Lowrance AA, Kass S, Tanigawa G, Vosberg HP, McKenna W, Seidman CE, Seidman JG. 1990. A molec- 
ular basis for familial hypertrophic cardiomyopathy: A $\beta$ cardiac myosin heavy chain gene missense mutation. Cell 62: 999-1006.

Girolami F, Ho CY, Semsarian C, Baldi M, Will ML, Baldini K, Torricelli F, Yeates L, Cecchi F, Ackerman MJ, et al. 2010. Clinical features and outcome of hypertrophic cardiomyopathy associated with triple sarcomere protein gene mutations. J Am Coll Cardiol 55: 1444-1453.

Golbus JR, Puckelwartz MJ, Fahrenbach JP, Dellefave-Castillo LM, Wolfgeher D, McNally EM. 2012. Populationbased variation in cardiomyopathy genes. Circ Cardiovasc Genet 5: 391-399.

Groenendyk J, Sreenivasaiah PK, Kim DH, Agellon LB, Michalak M. 2010. Biology of endoplasmic reticulum stress in the heart. Circ Res 107: 1185-1197.

Guo W, Schafer S, Greaser ML, Radke MH, Liss M, Govindarajan T, Maatz H, Schulz H, Li S, Parrish AM, et al. 2012. RBM20, a gene for hereditary cardiomyopathy. Nat Med 18: 766-773.

Herman DS, Lam L, Taylor MR, Wang L, Teekakirikul P, Christodoulou D, Conner L, De Palma SR, McDonough B, Sparks E, et al. 2012. Truncations of titin causing dilated cardiomyopathy. $\mathrm{N} \mathrm{Engl} \mathrm{J} \mathrm{Med} \mathrm{366:} \mathrm{619-628.}$

Hershberger RE, Siegfried JD. 2011. Update 2011: Clinical and genetic issues in familial dilated cardiomyopathy. $J$ Am Coll Cardiol 57: 1641-1649.

Hershberger RE, Parks SB, Kushner JD, Li D, Ludwigsen S, Jakobs P, Nauman D, Burgess D, Partain J, Litt M. 2008. Coding sequence mutations identified in MYH7, TNNT2, SCN5A, CSRP3, LBD3, and TCAP from 313 patients with familial or idiopathic dilated cardiomyopathy. Clin Transl Sci 1: 21-26.

Hershberger RE, Lindenfeld J, Mestroni L, Seidman CE, Taylor MR, Towbin JA. 2009. Genetic evaluation of cardiomyopathy_A Heart Failure Society of America practice guideline. J Card Fail 15: 83-97.

Hidalgo C, Granzier H. 2013. Tuning the molecular giant titin through phosphorylation: Role in health and disease. Trends Cardiovasc Med 23: 165-171.

Ho CY. 2010. Genetics and clinical destiny: Improving care in hypertrophic cardiomyopathy. Circulation 122: $2430-$ 2440.

Hoedemaekers YM, Caliskan K, Majoor-Krakauer D, van de Laar I, Michels M, Witsenburg M, ten Cate FJ, Simoons ML, Dooijes D. 2007. Cardiac $\beta$-myosin heavy chain defects in two families with non-compaction cardiomyopathy: Linking non-compaction to hypertrophic, restrictive and dilated cardiomyopathies. Eur Heart J 28: 27322737.

Huttner IG, Trivedi G, Jacoby A, Mann SA, Vandenberg JI, Fatkin D. 2013. A transgenic zebrafish model of a human cardiac sodium channel mutation exhibits bradycardia, conduction-system abnormalities and early death. J Mol Cell Cardiol 61: 123-132.

Itzhaki I, Maizels L, Huber I, Zwi-Dantsis L, Caspi O, Winterstern A, Feldman O, Gepstein A, Arbel G, Hammerman H, et al. 2011. Modelling the long QTsyndrome with induced pluripotent stem cells. Nature 471: 225-229.

Kamisago M, Sharma SD, DePalma SR, Solomon S, Sharma P, McDonough B, Smoot L, Mullen MP, Woolf PK, Wigle ED, et al. 2000. Mutations in sarcomere protein genes as a cause of dilated cardiomyopathy. $N$ Engl J Med 343: $1688-1696$.

Karam S, Raboisson MJ, Ducreux C, Chalabreysse L, Millat G, Bozio A, Bouvagnet P. 2008. A de novo mutation of the $\beta$ cardiac myosin heavy chain gene in an infantile restrictive cardiomyopathy. Congenit Heart Dis 3: 138-143.

Kim C, Wong J, Wen J, Wang S, Wang C, Spiering S, Kan NC, Forcales S, Puri PL, Leone TC, et al. 2013. Studying arrhythmogenic right ventricular dysplasia with patientspecific iPSCs. Nature 494: 105-110.

Klaassen S, Probst S, Oechslin E, Gerull B, Krings G, Schuler P, Greutmann M, Hurlimann D, Yegitbasi M, Pons L, et al. 2008. Mutations in sarcomere protein gene in left ventricular noncompaction. Circulation 17: 2893-2901.

Klues HG, Schiffers A, Maron BJ. 1995. Phenotypic spectrum and patterns of left ventricular hypertrophy in hypertrophic cardiomyopathy: Morphologic observations and significance as assessed by two-dimensional echocardiography in 600 patients. J Am Coll Cardiol 26: 16991708.

Knollman BC. 2013. Induced pluripotent stem-cell-derived cardiomyocytes: Boutique science or valuable arrhythmia model? Circ Res 112: 969-976.

Landstrom AP, Ackerman MJ. 2012. Beyond the cardiac myofilament: Hypertrophic cardiomyopathy-associated mutations in genes that encode calcium-handling proteins. Curr Mol Med 12: 507-518.

Leach IM, van der Harst P, de Boer RA. 2010. Pharmacoepigenetics in heart failure. Curr Heart Fail Rep 7: 83-90.

LeWinter ML, Granzier HL. 2013. Titin is a major human disease gene. Circulation 127: 938-944.

Lieschke GJ, Currie PD. 2007. Animal models of human disease: Zebrafish swim into view. Nat Rev Genet 8: 353367.

Lieu DK, Liu J, Siu CW, McNerney GP, Tse HF, Abu-Khalil A, Huser T, Li RA. 2009. Absence of transverse tubules contributes to non-uniform $\mathrm{Ca}^{2+}$ wavefronts in mouse and human embryonic stem-cell-derived cardiomyocytes. Stem Cells Dev 18: 1493-1500.

Lombardi R, Rodriguez G, Chen SN, Ripplinger CM, Li W, Chen J, Willerson JT, Betocchi S, Wickline SA, Efimov IR, et al. 2009. Resolution of established cardiac hypertrophy and fibrosis and prevention of systolic dysfunction in a transgenic rabbit model of human cardiomyopathy through thiol-sensitive mechanisms. Circulation 119: 1398-1407.

MacArthur DG, Balusubramanian S, Frankish A, Huang N, Morris J, Walter K, Jostins L, Habegger L, Pickrell JK, Montgomery SB, et al. 2012. A systematic survey of loss-of-function variants in human protein-coding genes. Science 335: 823-828.

Mann SA, Castro ML, Ohanian M, Guo G, Zodgekar P, Sheu A, Stockhammer K, Thompson T, Playford D, Subbiah R, et al. 2012. R222Q SCN5A mutation is associated with reversible ventricular ectopy and dilated cardiomyopathy. J Am Coll Cardiol 60: 1566-1573.

Marcus FI, McKenna WJ, Sherrill D, Basso C, Bauce B, Bluemke DA, Calkins H, Corrado D, Cox MG, Daubert JP, et al. 2010. Diagnosis of arrhythmogenic right ventricular cardiomyopathy/dysplasia: Proposed modification of the Task Force criteria. Eur Heart J 31: 806-814. 
D. Fatkin et al.

Maron BJ, Maron MS. 2013. Hypertrophic cardiomyopathy. Lancet 381: 242-255.

Maron BJ, Towbin JA, Thiene G, Antzelevitch C, Corrado D, Arnett D, Moss AJ, Seidman CE, Young JB. 2006. Contemporary definitions and classification of the cardiomyopathies: An American Heart Association Scientific Statement from the Council on Clinical Cardiology, Heart Failure and Transplantation Committee; Quality of Care and Outcomes Research and Functional Genomics and Translational Biology Interdisciplinary Working Groups; and Council on Epidemiology and Prevention. Circulation 113: 1807-1816.

Maron BJ, Maron MS, Semsarian C. 2012. Genetics of hypertrophic cardiomyopathy after 20 years. J Am Coll Cardiol 60: 705-715.

McKenna WJ, Thiene G, Nava A, Fontaliran F, BlomstromLundqvist C, Fontaine G, Camerini F. 1994. Diagnosis of arrhythmogenic right ventricular dysplasia/cardiomyopathy. Task Force of the Working Group Myocardial and Pericardial Disease of the European Society of Cardiology and the Scientific Council on Cardiomyopathies of the International Society and Federation of Cardiology. Br Heart J 71: 215-218.

McNair WP, Sinagra G, Taylor MR, Di Lenarda A, Ferguson DA, Salcedo EE, Slavov D, Zhu X, Caldwell JH, Mestroni L. 2011. SCN5A mutations associate with arrhythmic dilated cardiomyopathy and commonly localize to the voltage-sensing mechanism. J Am Coll Cardiol 57: 21602168.

McNally EM, Golbus JR, Puckelwartz MJ. 2013. Genetic mutations and mechanisms in dilated cardiomyopathy. J Clin Invest 123: 19-26.

Mendell JT, Olson EN. 2012. MicroRNAs in stress signaling and human disease. Cell 148: 1172-1187.

Milan DJ, MacRae CA. 2008. Zebrafish genetic models for arrhythmia. Prog Biophys Mol Biol 98: 301-308.

Milan DJ, Jones IL, Ellinor PT, MacRae CA. 2006. In vivo recording of adult zebrafish electrocardiogram and assessment of drug-induced QT prolongation. Am J Physiol Heart Circ Physiol 291: H269-H273.

Millat G, Bouvagnet P, Chevalier P, Sebbag L, Dulac A, Dauphin C, Jouk PS, Delrue MA, Thambo JB, Le Metayer P, et al. 2011. Clinical and mutational spectrum in a cohort of 105 unrelated patients with dilated cardiomyopathy. Eur J Med Genet 54: e570-e575.

Milting H, Klauke B. 2008. Molecular genetics of arrhythmogenic right ventricular dysplasia/cardiomyopathy. Nat Clin Pract Cardiovasc Med 5: E1.

Moretti A, Bellin M, Welling A, Jung CB, Lam JT, Bott-Flugel L, Dorn T, Goedel A, Hohnke C, Hofmann F, et al. 2010. Patient-specific induced pluripotent stem-cell models for long-QT syndrome. N Engl J Med 363: 1397-1409.

Movassagh M, Choy MK, Knowles DA, Cordeddu L, Haider S, Down T, Siggens L, Vujic A, Simeoni I, Penkett C, et al. 2011. Distinct epigenomic features in end-stage failing human hearts. Circulation 124: 2411-2422.

Muchir A, Shan J, Bonne G, Lehnart SE, Worman HJ. 2009. Inhibition of extracellular signal-regulated kinase signaling to prevent cardiomyopathy caused by mutation in the gene encoding A-type lamins. Hum Mol Genet 18: $241-247$.
Ng SB, Buckingham KJ, Lee C, Bigham AW, Tabor HK, Dent KM, Huff CD, Shannon PT, Jabs EW, Nickerson DA, et al. 2010. Exome sequencing identifies the cause of a Mendelian disorder. Nat Genet 42: 30-35.

Norton N, Robertson PD, Rieder MJ, Zuchner S, Rampersaud E, Martin E, Li D, Nickerson DA, Hershberger MD. 2012. Evaluating pathogenicity of rare variants from dilated cardiomyopathy in the exome era. Circ Cardiovasc Genet 5: 167-174.

Oechslin E, Jenni R. 2011. Left ventricular non-compaction revisited: A distinct phenotype with genetic heterogeneity? Eur Heart J 32: 1446-1456.

Ohanian M, Humphreys DT, Anderson E, Preiss T, Fatkin D. 2013. A heterozygous variant in the human cardiac miR133 gene, MIR133A2, alters miRNA duplex processing and strand abundance. BMC Genetics 14: 18.

Olivotto I, Cecchi F, Casey SA, Dolara A, Traverse JH, Maron BJ. 2001. Impact of atrial fibrillation on the clinical course of hypertrophic cardiomyopathy. Circulation 104: 2517-2524.

Pan S, Caleshu CA, Dunn KE, Foti MJ, Moran MK, Soyinka O, Ashley EA. 2012. Cardiac structural and sarcomere genes associated with cardiomyopathy exhibit marked intolerance of genetic variation. Circ Cardiovasc Genet 5: 602-610.

Pantazis AA, Elliott PM. 2009. Left ventricular noncompaction. Curr Opin Cardiol 24: 209-213.

Papait R, Greco C, Kunderfranco P, Latronico MV, Condorelli G. 2013. Epigenetics: A new mechanism of regulation of heart failure? Basic Res Cardiol 108: 361.

Parvatiyar MS, Pinto JR, Dweck D, Potter JD. 2010a. Cardiac troponin mutations and restrictive cardiomyopathy. $J$ Biomed Biotechnol 2010: 350706.

Parvatiyar MS, Pinto JR, Liang J, Potter JD. 2010b. Predicting cardiomyopathic phenotypes by altering $\mathrm{Ca}^{2+}$ affinity of cardiac troponin C. J Biol Chem 285: 2778527797.

Patel R, Nagueh SF, Tsybouleva N, Abdellatif M, Lutucuta S, Kopelen HA, Quinones MA, Zoghbi WA, Entman ML, Roberts R, et al. 2001. Simvastatin induces regression of cardiac hypertrophy and fibrosis and improves cardiac function in a transgenic rabbit model of human hypertrophic cardiomyopathy. Circulation 104: 317-324.

Petretta M, Pirozzi F, Sasso L, Paglia A, Bonaduce D. 2011. Review and meta-analysis of the frequency of familial dilated cardiomyopathy. Am J Cardiol 108: 11711176.

Pinto JR, Yang SW, Hitz MP, Parvatiyar MS, Jones MA, Liang J, Kokta V, Talajic M, Tremblay N, Jaeggi M, et al. 2011. Fetal cardiac troponin isoforms rescue the increased $\mathrm{Ca}^{2+}$ sensitivity produced by a novel double deletion in cardiac troponin T linked to restrictive cardiomyopathy: A clinical, genetic and functional approach. J Biol Chem 286: 20901-20912.

Priori SG, Napolitano C, Di Pasquale E, Condorelli G. 2013. Induced pluripotent stem-cell-derived cardiomyocytes in studies of inherited arrhythmias. J Clin Invest 123: 84-91.

Probst S, Oechslin E, Schuler P, Greutmann M, Boye P, Knirsch W, Berger F, Thierfelder L, Jenni R, Klaassen S. 2011. Sarcomere gene mutations in isolated left ventric- 
ular noncompaction cardiomyopathy do not predict clinical phenotype. Circ Cardiovasc Genet 4: 367-374.

Rao PK, Toyama Y, Chiang HR, Gupta S, Bauer M, Medvid R, Reinhardt F, Liao R, Krieger M, Jaenisch R, et al. 2009. Loss of cardiac microRNA-mediated regulation leads to dilated cardiomyopathy and heart failure. Circ Res 105: 585-594.

Richard P, Charron P, Carrier L, Ledeuil C, Cheav T, Pichereau C, Benaiche A, Isnard R, Dubourg O, Burban M, et al. 2003. Hypertrophic cardiomyopathy: Distribution of disease genes, spectrum of mutations and implications for a molecular diagnosis strategy. Circulation 107: 22272232.

Richardson P, McKenna W, Bristow M, Maisch B, Mautner B, O'Connell J, Olsen E, Thiene G, Goodwin J, Gyarfas I, et al. 1995. Report of the 1995 World Health Organization/International Society and Federation of Cardiology Task Force on the definition and classification of cardiomyopathies. Circulation 93: 841-842.

Sachdev B, Takenaka T, Teraguchi H, Tei C, Lee P, McKenna WJ, Elliott PM. 2002. Prevalence of Anderson-Fabry disease in male patients with late onset hypertrophic cardiomyopathy. Circulation 105: 1407-1411.

Saltzman AJ, Mancini-DiNardo D, Li C, Chung WK, Ho CY, Hurst S, Wynn J, Care M, Hamilton RM, Seidman GW, et al. 2010. The cardiac myosin binding protein C Arg502Trp mutation: A common cause of hypertrophic cardiomyopathy. Circ Res 106: 1549-1552.

Sander JD, Cade L, Khayter C, Reyon D, Peterson RT, Joung JK, Yeh JR. 2011. Targeted gene disruption in somatic zebrafish cells using engineered TALENs. Nat Biotechnol 29: 697-698.

Santoriello C, Zon LI. 2012. Hooked! Modeling human disease in zebrafish. J Clin Invest 122: 2337-2343.

Schmitt JP, Kamisago M, Asahi M, Li GH, Ahmad F, Mende U, Kranias EG, MacLennan DH, Seidman JG, Seidman CE. 2003. Dilated cardiomyopathy and heart failure caused by a mutation in phospholamban. Science 299: 1410-1413.

Schmitt JP, Debold EP, Ahmad F, Armstrong A, Frederico A, Conner DA, Mende U, Lohse MJ, Warshaw D, Seidman $\mathrm{CE}$, et al. 2006. Cardiac myosin missense mutations cause dilated cardiomyopathy in mouse models and depress molecular motor function. Proc Natl Acad Sci 103: 14525-14530.

Schonrock N, Harvey RP, Mattick JS. 2012. Long noncoding RNAs in cardiac development and pathophysiology. Circ Res 111: 1349-1362.

Seidman CE, Seidman JG. 2011. Identifying sarcomere gene mutations in hypertrophic cardiomyopathy: A personal history. Circ Res 108: 743-750.

Semsarian C, Ahmad I, Giewat M, Georgakopoulos D, Schmitt JP, McConnell BK, Reiken S, Mende U, Marks AR, Kass DA, et al. 2002. The L-type calcium channel inhibitor diltiazem prevents cardiomyopathy in a mouse model. J Clin Invest 109: 1013-1020.

Sen-Chowdry S, Syrris P, McKenna WJ. 2010. Genetics of restrictive cardiomyopathy. Heart Fail Clin 6: 179186.

Shan L, Makita N, Xing Y, Watanabe S, Futatani T, Ye F, Saito K, Ibuki K, Watanabe K, Hirono K, et al. 2008. SCN5A variants in Japanese patients with left ventricular noncompaction and arrhythmias. Mol Genet Metab 93: 468474.

Sikkema-Raddatz B, Johansson LF, de Boer EN, Almomani R, Boven LG, van den Berg MP, van Spaendonck-Zwarts KY, van Tintelen JP, Sijmons RH, Jongbloed JD, et al. 2013. Targeted next-generation sequencing can replace Sanger sequencing in clinical diagnostics. Hum Mutat 34: $1035-1042$.

Sun N, Yazawa M, Liu J, Han L, Sanchez-Freire V, Abilez OJ, Navarette EG, Hu S, Wang L, Lee A, et al. 2012. Patientspecific induced pluripotent stem cells as a model for familial dilated cardiomyopathy. Sci Transl Med 18: $130 \mathrm{ra} 47$.

Takahashi K, Yamanaka S. 2006. Induction of pluripotent stem cells from mouse embryonic and adult fibroblast cultures by defined factors. Cell 126: 663-676.

Teekakirikul P, Kelly MA, Rehm HL, Lakdawala NK, Funke BH. 2013. Inherited cardiomyopathies: Molecular genetics and clinical genetic testing in the postgenomic era. $J$ Mol Diagn 15: 158-170.

Thum T, Galuppo P, Wolf C, Fiedler J, Kneitz S, van Laake LW, Doevendans PA, Mummery CL, Borlak J, Haverich A, et al. 2007. MicroRNAs in the human heart: A clue to fetal gene reprogramming. Circulation 116: 258-267.

Tiso N, Stephan DA, Nava A, Bagattin A, Devaney JM, Stanchi F, Larderet G, Brahmbhatt B, Brown K, Bauce $\mathrm{B}$, et al. 2001. Identification of mutations in the cardiac ryanodine receptor gene in families affected with arrhythmogenic right ventricular cardiomyopathy type 2 (ARVD2). Hum Mol Genet 10: 189-194.

Udali S, Guarini P, Moruzzi S, Choi SW, Friso S. 2013. Cardiovascular epigenetics: From DNA methylation to microRNAs. Mol Aspects Med 34: 883-901.

Van Rooij E, Sutherland LB, Liu N, Williams AH, McAnally J, Gerard RD, Richardson JA, Olson EN. 2006. A signature pattern of stress-responsive microRNAs that can evoke cardiac hypertrophy and heart failure. Proc Natl Acad Sci 103: 18255-18260.

van Spaendonck-Zwarts KY, van Rijsingen IA, van den Berg MP, Lekanne Deprez RH, Post JG, van Mil AM, Asselbergs FW, Christiaans I, van Langen IM, Wilde AA, et al. 2013. Genetic analysis in 418 index patients with idiopathic dilated cardiomyopathy: Overview of 10 years' experience. Eur J Heart Fail 15: 628-636.

van Tintelen JP, Entius MM, Bhuiyan ZA, Jongbloed R, Wiesfeld AC, Wilde AA, van der Smagt JA, Boven LG, Mannens MM, van Langen IM, et al. 2006. Plakophilin-2 mutations are the major determinant of familial arrhythmogenic right ventricular dysplasia/cardiomyopathy. Circulation 113: $1650-1658$.

Verkerk AO, Remme CA. 2012. Zebrafish: A novel research tool for cardiac ( patho) electrophysiology and ion channel disorders. Front Physiol 3: 255.

Vermeer AM, van Engelen K, Postma AV, Baars MJ, Christiaans I, De Haij S, Klaassen S, Mulder BJ, Keavney B. 2013. Ebstein anomaly associated with left ventricular noncompaction: An autosomal dominant condition that can be caused by mutations in MYH7. Am J Med Genet C Semin Med Genet 163C: 178-184.

Watkins H, McKenna WJ, Thierfelder L, Suk HJ, Anan R, O’Donoghue A, Spirito P, Matsumori A, Moravec CS, 


\section{Fatkin et al.}

Seidman JG, et al. 1995. Mutations in the genes for cardiac troponin Tand $\alpha$-tropomyosin in hypertrophic cardiomyopathy. N Engl J Med 332: 1058-1064.

Watkins H, Ashrafian H, Redwood C. 2011. Inherited cardiomyopathies. N Engl J Med 364: 1643-1656.

Webster G, Berul CI. 2013. An update on channelopathies: From mechanisms to management. Circulation 127: $126-140$.

WHO/ISFC Task Force. 1980. Report of the WHO/ISFC task force on the definition and classification of cardiomyopathies. Br Heart J 44: 672-673.

Willat RH, Gomes AV, Chang AN, Parvatiyar MS, Pinto JR, Potter JD. 2010. Mutations in troponin that cause HCM,
DCM and RCM: What can we learn about thin filament function? J Mol Cell Cardiol 48: 882-892.

Worthey EA, Mayer AN, Syverson GD, Helbling D, Bonacci BB, Decker B, Serpe JM, Dasu T, Tschannen MR, Veith RL, et al. 2011. Making a definitive diagnosis: Successful clinical application of whole exome sequencing in a child with intractable inflammatory bowel disease. Genet Med 13: $255-262$.

Yeoh T, Hayward CS, Benson V, Sheu A, Richmond Z, Feneley MP, Keogh AM, Macdonald P, Fatkin D. 2011. A randomised, placebo-controlled trial of carvedilol in early familial dilated cardiomyopathy. Heart Lung Circulation 20: $566-573$. 


\title{
$\&_{\mathrm{CSH}}^{\infty} \&$ Cold Spring Harbor

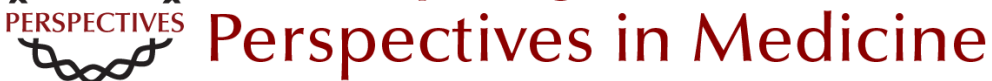

\section{Genetics and Disease of Ventricular Muscle}

\author{
Diane Fatkin, Christine E. Seidman and Jonathan G. Seidman \\ Cold Spring Harb Perspect Med 2014; doi: 10.1101/cshperspect.a021063
}

Subject Collection The Biology of Heart Disease

The Genetic Basis of Aortic Aneurysm Mark E. Lindsay and Harry C. Dietz

\section{Personalized Genomes and Cardiovascular Disease Kiran Musunuru}

Complex Genetics and the Etiology of Human Congenital Heart Disease

Bruce D. Gelb and Wendy K. Chung

Genetic Networks Governing Heart Development Ashley J. Waardenberg, Mirana Ramialison, Romaric Bouveret, et al.

Heart Fields and Cardiac Morphogenesis Robert G. Kelly, Margaret E. Buckingham and Antoon F. Moorman

Regenerative Medicine: Transforming the Drug Discovery and Development Paradigm Sotirios K. Karathanasis

Myocardial Tissue Engineering: In Vitro Models Gordana Vunjak Novakovic, Thomas Eschenhagen and Christine Mummery

Pluripotent Stem Cell Models of Human Heart

Disease

Alessandra Moretti, Karl-Ludwig Laugwitz, Tatjana

Dorn, et al.
Cardiac Cell Lineages that Form the Heart Sigolène M. Meilhac, Fabienne Lescroart, Cédric Blanpain, et al.

Synthetic Chemically Modified mRNA (modRNA):

Toward a New Technology Platform for

Cardiovascular Biology and Medicine Kenneth R. Chien, Lior Zangi and Kathy O. Lui

Next-Generation Models of Human Cardiogenesis via Genome Editing

Xiaojun Lian, Jiejia Xu, Jinsong Li, et al.

How to Make a Heart Valve: From Embryonic Development to Bioengineering of Living Valve Substitutes

Donal MacGrogan, Guillermo Luxán, Anita Driessen-Mol, et al.

Insights into the Genetic Structure of Congenital Heart Disease from Human and Murine Studies on Monogenic Disorders Terence Prendiville, Patrick Y. Jay and William T. $\mathrm{Pu}$

Cardiovascular Drug Discovery: A Perspective from a Research-Based Pharmaceutical Company G. Gromo, J. Mann and J.D. Fitzgerald

Genetics and Disease of Ventricular Muscle Diane Fatkin, Christine E. Seidman and Jonathan G. Seidman

Embryonic Heart Progenitors and Cardiogenesis Thomas Brade, Luna S. Pane, Alessandra Moretti, et al.

For additional articles in this collection, see http://perspectivesinmedicine.cshlp.org/cgi/collection/ 